photometer and allied instruments. There is also a general purpose chemical laboratory containing large apparatus, such as a centrifuge and a deep freeze, and provided with fixed service panels and mobile benches to allow flexibility of arrangement.

Techniques for controlling pests on planting material either imported or destined for export will be studied in a new fumigation section, starting with methyl bromide fumigation of seeds and continuing with the effect of fumigants on a number of pests and plant species. A large general-purpose laboratory is intended to be used for gas analysis studies and for the biological aspects of the work. In the three airconditioned rooms temperatures can be controlled between $5^{\circ}$ and $30^{\circ} \mathrm{C}$., and high relative humidities can be maintained, in order to be able to simulate some of the conditions which obtain during practical plant quarantine work. One room will house a 1.500litre steel fumigation chamber for plant toxicity studies and for work on vacuum fumigation techniques, while the other two will be used for small-scale studies on the sorption of fumigants by seeds and for the rearing of insect pests.

Ancillary buildings adjoin the main laboratory. The glasshouse block includes insectaries, glasshouses of a total area of 2,000 sq. ft. divided into a number of isolated compartments, a small laboratory for plant inoculations, and a working area with potting bench, etc. Ventilators are protected by removable metal gauze panels, so that any compartment can be made aphid proof. The virus disease section has additional forced fan ventilation. The bench tops are concrete troughs so that the plants can be watered by subirrigation. The glasshouses are heated by small-bore hot-water pipes and auxiliary electric fan heaters, both thermostatically controlled; and there are facilities for supplementary lighting when required.

The ancillary buildings also include a room specially designed for washing soil samples to determine pest populations of soils, and a pest assessment sample room equipped to deal annually with large numbers of experimental yield samples of cereals and forage crops. A small, unique, electrically driven, highly versatile, loss-free threshing machine, designed and built at the National Institute of Agricultural Engineering, has been installed along with other equipment, including a sample dryer which can deal with wet samples before threshing as well as grain after threshing, and a modified small commercial grain cleaner.

\title{
OBITUARIES
}

\section{Mr. H. W. Robinson}

H. W. Ropinson, who died suddenly on April 22, was a farniliar and much-consulted figure in the Library of the Royal Society, with which his associa. tion was so long, so close and so valuable that the loss seems irreparable. He was born on March 23, 1888, in Wood Green, a part of London with which he was closely associated all his life, being in many ways a prominent local figure, held in affectionate regard by the residents. He joined the staff of the Royal Socioty in 1902, as a boy of fourteen, and soon became particularly associated with the Library, of which he was appointed assistant librarian in 1930 and librarian in 1935. When, at the ago of sixty, he retired from this post, his services were retained by the Society to assist in editing the Newton correspondence, of which, happily, he was spared to see the appearance, some months ago, of the first of the seven volumes that are anticipated. With this work, to which his contributions were a model of clarity and accuracy, he was prominently associated until the day of his death.

Robinson took an enthusiastic interest in everything to do with the Royal Society's Library and with its extensive and invaluable archives. He was a self-taught scholar of considerable attainments, whose specialized acquiaintance with many branches of the history of science was remarkable. He was always ready to place this exceptional knowledge, which included the whereabouts of rare books and manuscripts other than those in the Society's possession, at the disposal of siudents of the history of science, including many from abroad who made use of the Library, and frank acknowledgments of his generous and valuable aid are to be found in many important publications. With Prof. Harcourt Brown and Prof. D. M. McKie he founded the Annals of Science and he took a prominent part in founding the British Society for the History of Science.
$\mathrm{H}_{\Theta}$ was particularly well acquainted with the events of the early days of the Royal Society. He had, for example, made a particular study of Robert Hooke : he identified as written by Hooke the diary in the British Museum that had always been attributed to James Petiver, and, in conjunction with Walter Adams, he edited the "Diary of Robert Hooke", in the possession of Guildhall Library, which was published in 1935. Reference has already been made to his exceptional knowledge of the correspondenco of Newton and his contemporaries.

Robinson was a most friendly man, who know his own mind and inspired confidence. He was devoted to the Royal Society, which he served for fifty-eight years, and the Society repaid his devotion with a warm regard and a respect for his specialized knowledge and achievements. He was very happy when his son Norman was appointed assistant librarian to the Royal Society, thus continuing the association which Robinson himself so long represented.

E. N. DA C. ANDrade

\section{Mr. J. R. MacCabe}

JACK R. MACCABE, a familiar figure to the many visitors to the European Organization for Nuclear Research, died on April 17.

Born at Edmonton, Canada, on May 4, 1914, he entered the University of Alberta in 1930. Two years later, he went to McGill University, Montreal, where, by 1937, he had taken his degrees of bachelor of science and master of science (natural sciences), while working as a demonstrator and lecturer in physiology at the University's Faculty of Medicine.

Jack. MacCabe went to Europe soon after finishing at McGill and continued medical and biological studies and research at the University of Munich, up to the outbreak of the Second World War in 1939. When he arrived in Switzerland, he found a position as a lecturer at the International School and at the 